Emir. J. Food Agric. 2009. 21 (2): 34-41

http://cfa.uaeu.ac.ae/ejfa.shtml

\title{
Detection of anti-fungal genes in chickpea (Cicer arietinum L.) and their effects on fungal growth
}

\author{
A. A. Shahid, B. Chaudhry, Mahmood-ur-Rahman and S. Riazuddin \\ National Centre of Excellence in Molecular Biology, 87-West Canal Bank Road, \\ Thoker Niaz Baig, Lahore-53700, Pakistan
}

\begin{abstract}
Anti-fungal genes chitinase, beta-glucanase and ribosomal inactivating proteins (RIP) were detected in chickpea plants when they were artificially exposed to Ascochyta rabei spores. Immunological studies provided evidence for the presence of a chitinase-like proteins in blightinfected chickpea leaves using a poplar chitinase antibody. No activity was detected when a barley chitinase antibody was used, indicating that antifungal proteins in chickpea recognize different antigenic determinants. Purified barley ribosomal inactivating protein (RIP 30) and chitinase (Chi 26) were shown to inhibit the growth of Ascochyta rabiei in vitro. The role of antifungal proteins in the protection of chickpea against pathogen is discussed.
\end{abstract}

Key words: Ascochyta rabiei, $\beta$-glucanase, Cicer arietinum, Chitinase, Ribosomal Inactivating Protein.

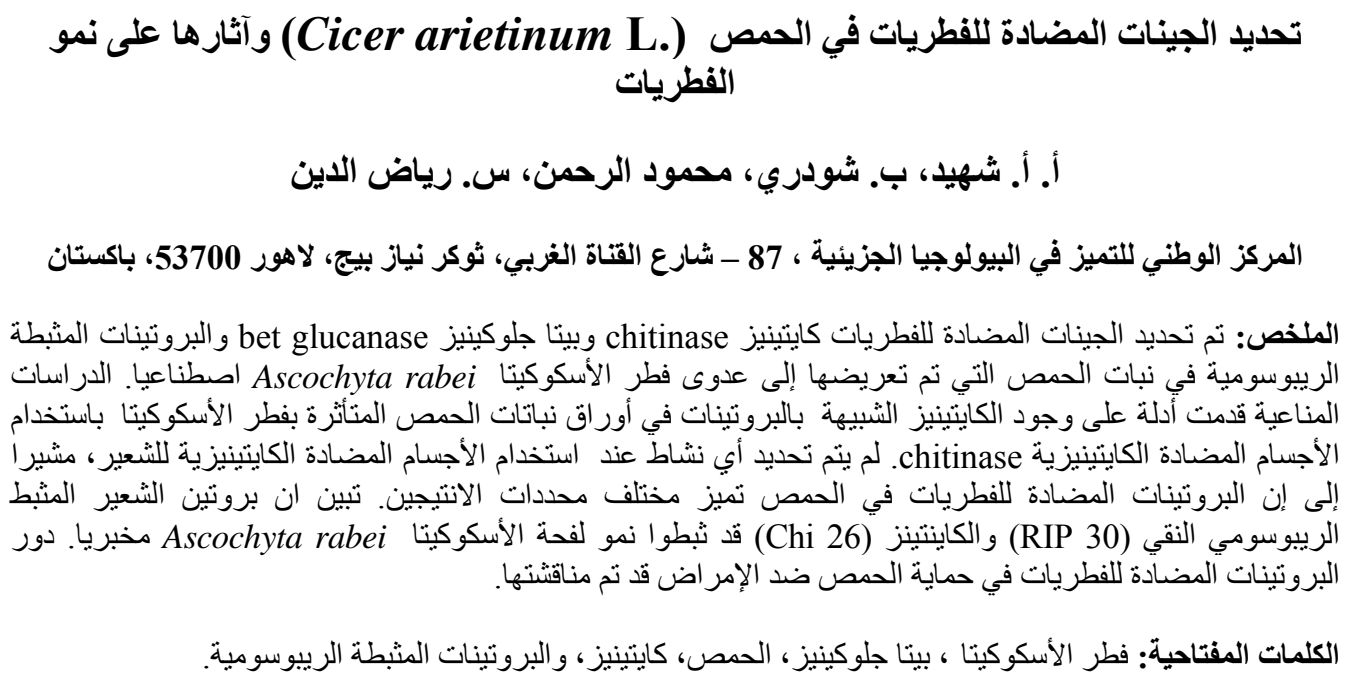

\section{Introduction}

Chickpea (Cicer arietinum L.) is an important legume crop and a source of quality protein. It is cultivated on approximately 10 million hectares in more that 40 countries worldwide, with $95 \%$ cultivation in developing countries (ICRISAT, 2004). However, its productivity is low in developing countries due to several reasons including poor agricultural practices, use of low yielding varieties, insect pests and diseases. Chickpea blight caused by
Ascochyta rabiei L. is one of most devastating disease (Pande et al., 2005) and causes significant yield loss (Davidson and Kimber, 2007).

Plants use various self defense mechanisms to protect themselves from pathogenic infections (Boller, 1985; Yedidia et al., 1999). These mechanisms include inducible modifications to plant cell walls, the synthesis of toxic phytoalexins, and the accumulation of pathogenesis resistant proteins such as protease inhibitors or pathogen targeted 
hydrophytic enzymes (Cho and Muehlbauer, 2004; Darvill and Albersheim, 1984; Pernas et al., 2000; Van Loon, 1985). Examples of the latter group are chitinase and $\beta 1-3$ glucanase, which are synthesized in the vegetative tissues of many plants in response to fungal invasion (Legrand et al., 1987). These enzymes limit fungal growth by degrading chitin and $\beta$ 1-3 glucans, which comprise major structural polysaccharides of fungal cell walls (Boller, 1987). Chitinase and $\beta$ 1-3 glucanase are thus involved in self defense mechanism of plant and host signaling during pathogen attack.

Many scientists isolated ribosomal inactivating proteins (RIPs) which are produced in the plants in response to fungal pathogens and thus act as antifungal agents. Park et al., (2002) isolated a novel type-1 RIP from root culture of pokeweed (Phytolacca americana). Leah et al., (1991) isolated three RIPs from barley seeds (Hordeum vulgare L.), which synergistically inhibited the growth of Trichoderma reesei and Fusarium sporotrichioides. Coram and Pang (2006) studied resistant genes in chickpea during attack of Ascochyta blight. RIPs were also isolated from maize (Bass et al., 2004) and differential regulation of these proteins in maize suggests that they may be involved in defense-related functions.

Currently, the level of resistance in cultivated chickpea is not sufficient to withstand disease pressure. So, it is needed to study the mechanisms of internal defense system of crop plants. The aim of present study was to understand the defense mechanism of chickpea against $A$. rabeie under artificial infestation conditions and effects of antifungal proteins on its growth. This study may lead to develop the understanding of internal defense mechanism in chickpea against fungal diseases.

\section{Materials and Methods}

\section{Plant growth}

Chickpea cultivar (CM72) was obtained from Nuclear Institute of Agriculture and Biology (NIAB), Faisalabad, Pakistan and grown in pots under natural environmental conditions. After four months, the plants were sprayed with a spore suspension of $A$. rabiei $\left(10^{5}\right.$ spore $\left./ \mathrm{ml}\right)$ and then kept in $100 \%$ humidity. After 48 hours of infection, the samples from leaves, stems and pods were collected from affected with fungus and control (un-affected) plants. These samples were frozen in $70^{\circ} \mathrm{C}$ freezer until further studies.

\section{Probe labeling, hybridization and detection}

The ECL direct nucleic acid labeling and detection system (Amersham) was used for labeling of Chi26 and bgl32 probes. The probes were labeled, hybridized and detected according to the instructions provided by manufacturer.

\section{Plant genomic DNA isolation and Southern blotting}

Frozen samples were taken from $70^{\circ} \mathrm{C}$ freezer and $1 \mathrm{~g}$ of each of the sample was ground into fine powder in liquid nitrogen. The powder was immediately resuspended in extraction buffer $(100 \mathrm{mM} \mathrm{HCl}, 200 \mathrm{mM}$ EDTA, $500 \mathrm{mM} \mathrm{NaCl}, 1 \%$ Sarkosyle) and incubated at $55^{\circ} \mathrm{C}$ for two hours. DNA was isolated according to the method described by Ausubel et al., (1990). The DNA was digested with BamHI, EcoRI and/or HindIII restriction enzymes at $37^{\circ} \mathrm{C}$ for over night. The digested DNA was separated on $0.8 \%(\mathrm{w} / \mathrm{v})$ agarose gel. A standard capillary transfer by the method of Southern, (1975) was used to blot DNA onto Hybond-N nylon membranes (Amersham). 


\section{RNA isolation and Northern blotting}

The samples were taken from $-70^{\circ} \mathrm{C}$ freezer and $1 \mathrm{~g}$ of each sample was ground into fine powder in liquid nitrogen and transferred to $12 \mathrm{ml}$ of ice cold denaturing solution $(40 \mathrm{mM}$ sodium citrate, $0.83 \%$ sarcosine, $0.2 \mathrm{M}$ Betamercaptoethanol and guanidine thiocyanate). RNA was isolated according to the method described in Promega technical bulletin number 082 . Sixty $\mu \mathrm{g}$ of RNA was separated on $1 \%$ $(\mathrm{w} / \mathrm{v})$ formaldehyde-agarose gel and transferred to Hybond-N nylon membranes (Amersham). The integrity of the RNA was assessed by visualization of ribosomal RNA with ethidium bromide staining. Standard capillary transfer by the method of Southern, (1975) was used to blot RNA onto Nylon membranes.

\section{Preparation of protein extracts and immunobloting}

One gram of chickpea plant material was ground to a fine powder in liquid nitrogen. The ground material was resuspended in one $\mathrm{mL}$ ice cold NEB extraction buffer $(10 \mathrm{mM}$ Tris, $\mathrm{HCl}$, pH7.5, 25mM PMSF, 40mM, EDTA, $150 \mathrm{mM}$ Nacl, $10 \%$ glycerol and $50 \mathrm{mM}$ DTT) in $1.5 \mathrm{ml}$ tube and centrifuged at $40^{\circ} \mathrm{C}$ for 15 minutes at $14000 \mathrm{rpm}$. The clear supernatant was used to measure the concentration of protein according to the method described by Bradford, (1976).

The protein of infected/un-infected chickpea plant material was solubilized in sample buffer and loaded on $12.5 \%$ SDSpolyacrylamide gel. After electrophoresis the proteins were transferred by semi-dry electrophoresis onto nitrocellulose filters. Immuno- blot analysis was carried out by the method described by Towbin et al., (1979).

\section{Antifungal activity of protein on $A$. rabiei}

Fungus was grown on agar medium according to the procedure described by Leah et al., (1991). Spores of A. rabiei were spread on to the medium and incubated in a fungus growth room at 22 ${ }^{\circ} \mathrm{C}$. After 2-3 days, purified barley RIP and/or chitinase (Chi), and in combination were studied against the growth of $A$. rabiei on sterilized discs of white filter paper. In microtiter well plate assay the effect of these proteins on spore germination was recorded after 48 hours.

\section{Results}

\section{Detection of antifungal genes in chickpea}

Probing of chickpea genomic DNA with barley chitinase gene revealed a number of hybridizing fragments. The size of these fragments varied depending on the enzymes used for restriction. It showed homology by giving significant signals at the levels of $4.3,9.4 \& 23.0 \mathrm{~Kb}$ with Chi26 probe (Figure 1A) and 1.9, $3.5,6.5$ and $9.4 \mathrm{~Kb}$ with Bgl32 probe (Figure 1B), indicating the presence of antifungal genes in the chickpea. Chi 26 banding pattern of HindIII digest was different as compare to BamHI \& EcoRI but in probe Bgl32 the entire three enzymes presented different banding pattern.

\section{Antifungal genes do express in chickpea}

Northern blot analysis revealed the expression of Chi26 gene in chickpea plants. By using barley Chi26 as probe, the control leaves, stems and pods (with out infection) did not show any transcript level, whereas infected leaves and pods indicated 1.4 and $1.5 \mathrm{~Kb}$ transcript and infected stem presented $1.5 \& 1.9 \mathrm{~Kb}$ fragments (Figure $2)$. This represents the presence of antifungal like genes in chickpea under stress conditions. 


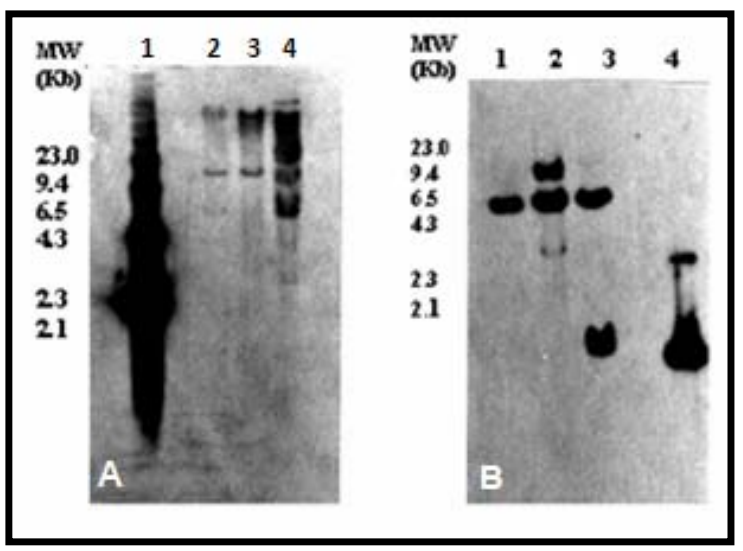

Figure 1. Southern blot analysis of chickpea genomic DNA: (A) Probe Chitinase (Chi 26). Lane 1: Chitinase (Chi 26); Lane 2-4: Genomic DNA digested with

BamHI, EcoRI and HindIII enzymes respectively. (B) Probe barley (Bgl 32). Lane 1-3: Genomic DNA digested with BamHI, EcoRI and HindIII enzymes respectively; Lane 4: Beta-glucanase (Bgl 32) fragment.

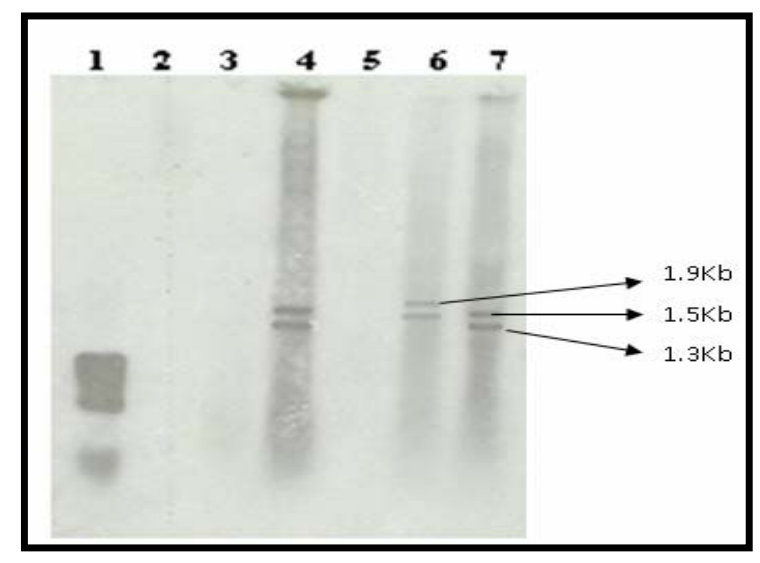

Figure 2. Northern blot analysis of chickpea RNA showing antifungal gene

fragments: Lane 1: Chitinase (Chi26) fragment; Lane 2, 3\&5: RNA of un-infected leaves, un-infected stems and un-infected pods; Lane 4, 6 \& 7: RNA of infected leaves, infected stems and infected pods respectively.

Immunological studies by western blot analysis using polyclonal antibodies against poplar chitinase were carried out and $66 \mathrm{KD}$ antifungal protein was detected in all samples (Figure 3). Expression level of antifungal like genes in infected leaves stems and pods was higher as compared to the un-affected samples (Figure 3). The infected leaves showed additional proteins of 55 and 14KD.

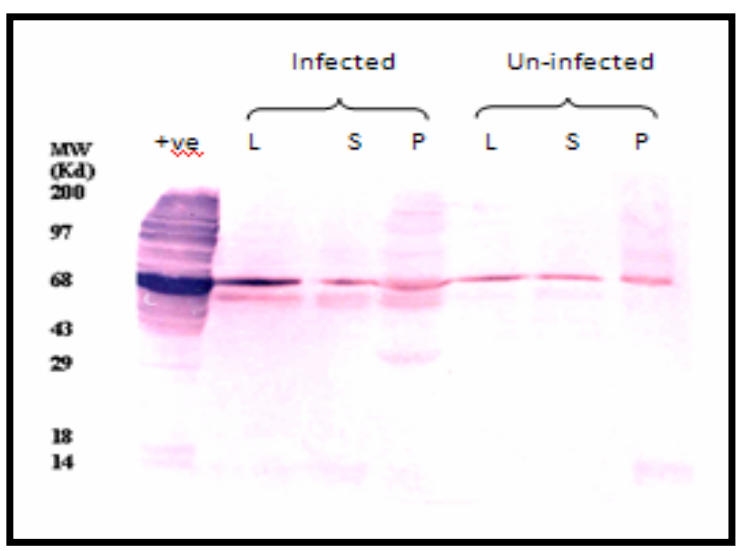

Figure 3. Western blot analysis of chickpea proteins: chitinase, protein of infected leaves, infected stems, infected pods, un-infected leaves, un-infected stem and uninfected pods respectively (from left to right).

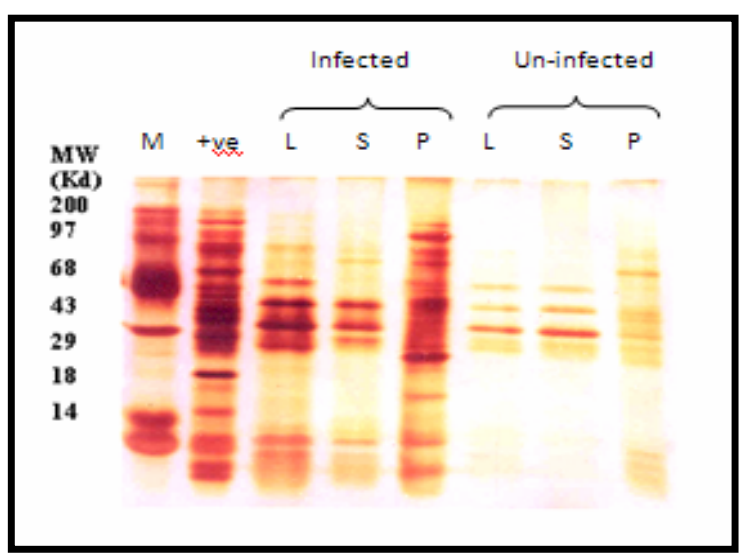

Figure 4. Silver stained gel of chickpea proteins relating to antifungal activity: Protein marker, chitinase, protein of infected leaves, infected stems, infected pods, un-infected leaves, un-infected stem and un-infected pods respectively (from left to right).

Two additional bands of 50 and 14KD were observed in infected stems. Infected pods also showed induced proteins of 95,80 and $70 \mathrm{KD}$ in addition to 55, 50 and $30 \mathrm{KD}$ (Figure 3). Overall results demonstrated different isoforms of chitinase like proteins present in precursor or as active form. Presence of same kind of proteins was also detected by silver stained SDS gel (Figure 4). 
Emir. J. Food Agric. 2009. 21 (2): 34-41

http://cfa.uaeu.ac.ae/ejfa.shtml

\section{Growth inhibition of $A$. rabiei}

Agar plate assay using barley purified chitinase and same gene expressing in bacteria inhibited the fungal growth (Figure 5 ) as indicated by the inhibitory zones.

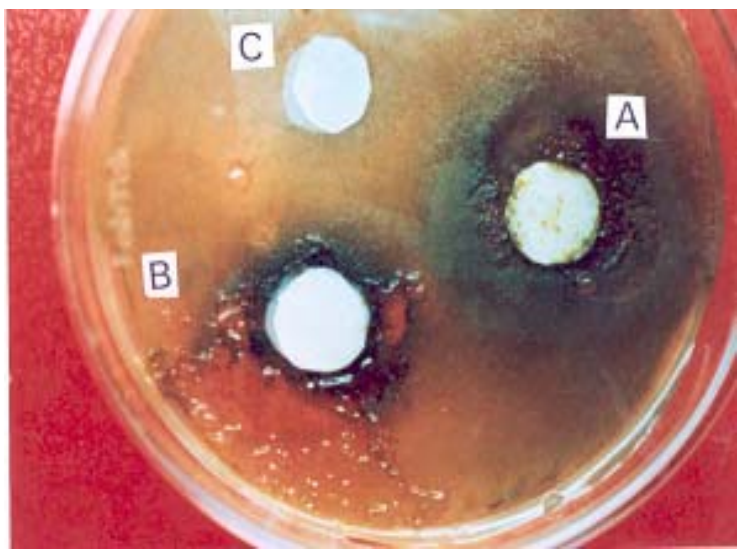

Figure 5. Effect of chitinase on growth of $A$. rabiei: A. Crude barley chitinase.B. Purified barley chitinase. C. Control.

Spore suspension of the fungus was added in wells of microtiter plate, followed by different concentrations of RIP and chitinase separately and in combination. They were incubated at $22 \pm 2{ }^{\circ} \mathrm{C}$ for 48 hours. After 48 hours spore germination was observed under microscope.

The antifungal activity was observed against $A$. rabeie growth (Figure 6). The percentage of spore germination was calculated by counting the spore under microscope. The spores were shrinked and deformed with the effect of RIP 30 (Figure 6C) and by the combination of both proteins, they were disintegrated (Figure 6D).

The combined effect of proteins was more pronounced as compare to single protein (Figure 7). A gradual decrease of spore germination was noticed with combination of RIP and chitinase (Figure 7).

\section{Discussion}

The plant hydrolases $\beta$-glucanase and Chitinase have attracted considerable interest as defence related genes in a wide variety of plants (Cutt and Klessig, 1992;
Chun et al., 2001; Coram et al., 2006). In this study the ability of defence related genes in chickpea was studied. Southern and northern blot analyses detected antifungal genes from chickpea using heterologus probes from barley antifungal chitinase (Chi26), 1-3 Betaglucanases (bgl32) and ribosomal inactivating protein (RIP). The genes have $50-60 \%$ homology to other antifungal genes.

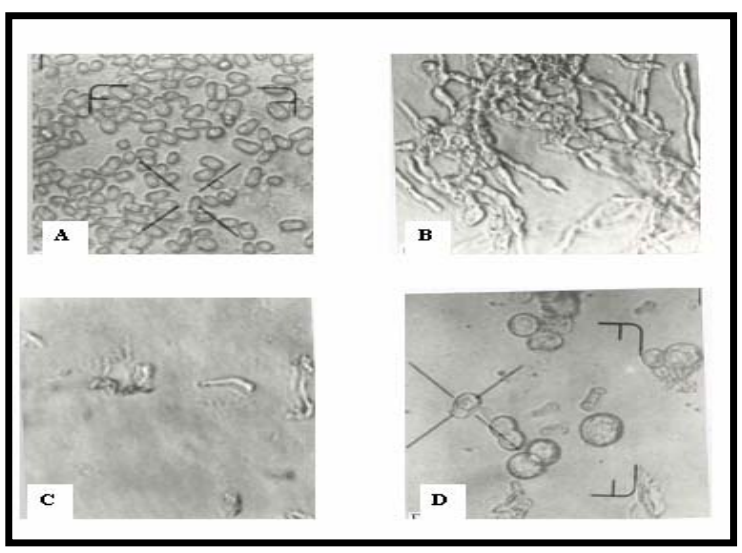

Figure 6. Effect of antifungal proteins on

A. rabiei: A. Control spores. X20. B. Control after 48 hours. X20. C. Effect of barley ribosome inactivating protein (RIP 30). X40.

D. Combine effect of barley (RIP 30) and chitinase. X40.

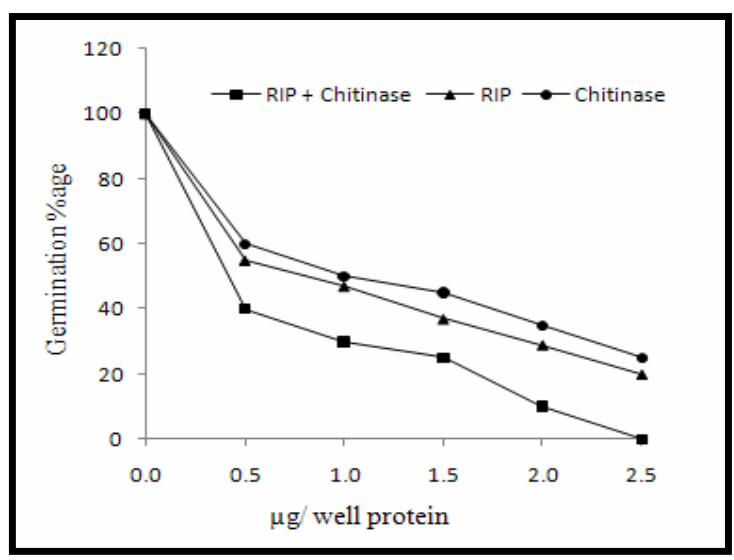

Figure 7. Effect of purified RIP 30 and Chi 26 (separately and in combination) on spore germination of $A$. rabiei.

Expression of defence genes under stress conditions indicated that there is internal defence mechanism of chickpea plants against pathogens. Their presence 
is in agreement with Mauch and Staehelin (Mauch and Staehelin, 1989) who suggested that bgl gene acts as a last line of defence when plant cells are lysed. Pritsch et al., (2000) reported defence related genes PR-1, PR-2 and PR-3 from wheat in response to fungal attack.

The antifungal protein detected by using poplar chitinase antibody showed the protein homology by using barley antibodies against chitinase. RIP and bg132 could not detect much protein indicating the difference in antigenic determinant of low protein levels. Kalaitzis, et al., (1999) identified an Endo-beta-1, 4-glucanase from tomato. Bartnicki-Garcia, (1968) has shown that chitinase and 1-3 Beta-glucanase inhibited fungal growth degrading chitin and 1-3 Beta-glucane major structural cell wall polysaccharides in growth hyphae. In present studies it is observed that purified chitinase inhibited the growth of $A$. rabiei. The spore germination was also inhibited by the purified antifungal proteins (RIP or chitinase) at concentrations as low as 0.5 $\mu \mathrm{g} / \mathrm{well}$, in microtiter well plate assay, indicating that the proteins are active as any reported elsewhere (Mauch et al., 1988). The inhibition was more pronounced when combination of both proteins was used suggesting that they synergistically retarded the fungal growth. The results presented here and elsewhere (Oldach et al., 2001; Roberts, 1986) indicate that single chain ribosomal inactivating proteins inhibit fungal growth. Using microarray technology, Coram and Pang, (2005) identified defence related genes from chichpea. Sharma et al., (2004) isolated a $26 \mathrm{KD}$ RIP from tobacco leaves and purified using ion exchange and gel filtration chromatography. Antimicrobial assays by using highly purified tobacco RIP conducted against various fungi and bacterial pathogens showed the strongest inhibitory activity.
The synergistic inhibition of fungal growth by the mixtures of RIP and chitinase suggests that inhibition by RIP can be enhanced with the combination of chitinase. Ability of these defence genes to inhibit $A$. rabiei growth suggest that they may be capable of inhibiting pathogenic infection in vivo. This information looks extremely valuable for developing genetic engineering strategies in making plant expression vectors to develop transgenic plants against Ascochyta blight of chickpea.

\section{Acknowledgements}

The authors are thankful to Dr. John Mundy, Copenhagen University, Denmark, for kindly providing purified barley Ribosomal Inactivating Protein (RIP 28) and Chitinase (Chi 26).

\section{References}

Ausubel, F., R. Brent, R. Kingston, D. Moore, J. Seidman and K. Struhl. 1990. Current Protocols in Molecular Biology, 2, A.1.5., John Wiley \& Sons, Inc. New York, NY.

Bartnicki-Garcia, S. 1968. Cell wall chemistry, morphogenesis and taxonomy of fungi. Ann. Rev. Microbiol. 22:87-109.

Bass, W. H., E. J. Krawetz, O. R. Brain, C. Zinscelmeier, E. J. Habben and S. R. Boston. 2004. Maize ribosome inactivating proteins (RIPs) with distinct expression patterns have similar requirements for proenzyme activation. J. Exp. B. 55(406):22192233.

Boller, T. 1988. Ethylene and the regulation of antifungal hydrolases in plants. Oxford Sur. Plant Mol. Cell Biol. 5:145-174. 
Emir. J. Food Agric. 2009. 21 (2): 34-41

http://cfa.uaeu.ac.ae/ejfa.shtml

Boller, T. 1985. Induction of hydrolases as a defence reaction against pathogens. In: Cellular and Molecular Biology of Plant Stress (Key J.L., T. Kosuge. eds.) Alan R Liss, New York pp. 247-262.

Bradford, M. M. 1976. A rapid and sensitive method for the quantitation of microgram quantities of protein utilizing the principle of protein-dye binding. Anal. Biochem. 72:248-254.

Cho, S. and F. J. Muehlbauer. 2004. Genetic effect of differentially regulated fungal response genes on resistance to necrotrophic fungal pathogens in chickpea (Cicer arietinum L.). Physiol. Mol. Plant Phathol. 64:57-66.

Chun, T. W., L. M. Gerhard, M. Federick and K. J. Bradford. 2001. Class I $\beta$ 1, 3-Glucanase and Chitinase are expressed in the micropylar endosperm of tomato seeds prior to radical emergence. Plant Physiol. 126:1299-1313.

Coram, T. E. and E. C. K. Pang. 2005. Isolation and analysis of candidate Ascochyta blight defence genes in chickpea. Physiol. Mol. Plant Phathol. 66:201-210.

Coram, T. E. and E. C. K. Pang. 2006. Expression profiling of chickpea genes differentially regulated during a resistance response to Ascochyta rabiei. Plant Biotechnol. J. 4:647.

Coram, T. E., N. E. Mantri, B. M. Mustafa, M. Harjati, R. Ford, P. Keane and E. C. K. Pang. 2006. The pulse chip: Discovering the sequence of gene activation for resistance to ascochyta blight in chickpea and other pulses. Plant and Animal Genomes XIV Conference. Town and Country

Convention Center San Diego, CA. (Abstr).

Cutt, J. R. and D. F. Klessig. 1992. Pathogenesis related proteins. In: Plant Gene Research, SpringerVerlag, New York. 209-243.

Darvill, A. G. and P. Albersheim. 1984. Phytoalexins and their elicitors: A defense against microbial infection in plants. Ann. Rev. Plant Physiol. 35:243-275.

Davidson, J. A. and R. B. E. Kimber. 2007. Integrated disease management of ascochyta blight in pulse crops. European J. Plant Pathol. 119:99-110.

ICRISAT. 2004. Chickpea. http://www. icrisat.org/ChickPea/Chickpea.htm\# 1.

Kalaitzis, P., S. B. Hong, T. Solomos and M. L Tucker. 1999. Molecular characterization of a tomato endo beta-1, 4-glucanase gene expressed in mature pistils, abscission zones and fruit. Plant Cell Physiol. 40(8):905908.

Leah, R., H. Tommerup, B. Svendsent and J. Mundy. 1991. Biochemical and molecular characterization of three barley seed proteins with antifungal properties. J. Biol. Chem. 266(3): 15641573.

Legrand, M., S. Kauffmann, P. Geoffroy and B. Fritig, 1987. Biological function of pathogenesis-related proteins: Four tobacco pathogenesisrelated proteins are chitinases. Proc. National Acad. Sci. USA. 84:67506754.

Mauch, F., B. Mauch-Mani and T. Boller. 1988. Inhibition of fungal growth by combination of chitinase and Beta-1, 
E A. A. Shahid et al.

3-glucanase. Plant Physiol. 88:936942.

Mauch, F., L. A. Staehelin. 1989. Functional implication of the subcellular localization of ethyleneenduced chitinase and beta- 1,3glucanase in bean leaves. Plant Cell. 1:447-457.

Oldach, K. H., D. Becker and H. Lorz. 2001. Hetrerologus expression of genes mediating enhanced fungal resistant in transgenic wheat. Mol. Plant Micr. Interact. 1:508.

Pande, S., K. H. M. Siddique, G. K. Kishore, B. Baaya, P. M. Gaur, C. L. L.Gowda, T. Bretag and J. H. Crouch. 2005. Ascochyta blight of chickpea (Cicer arietinum L.): A review of Biology, pathogenicity and disease management. Australian J. Agric. Res. 56(4):317-332.

Park, W. S., B. C. Lawrence, C. J. Linden and M. J. Vivanco. 2002. Isolation and characterization of a novel ribosomal inactivating protein from root culture of pokeweed and its mechanism of secretion from roots. Plant Physiol. 130:164-178.

Pernas, M., R. Sanchez-Monge and G. Salcedo, 2000. Biotic and abiotic stress can induce cystatin expression in chestnut. FEBS Lett. 467:206-210.

Pritsch, C., G. J. Muehlbauer, W. R. Bushnell, D. A. Somers and C. P. Vance, 2000. Fungal development and induction of defence response genes during early infection of wheat spikes by Fusarium graminearum. Mol. Plant Micr. Interact. 13(2):159-169.
Roberts, W. K. and C. P. Selitrennikoff. 1986. Isolation and partial characterization of two antifungal proteins from barley. Biochem. Biophys. Acta 880:161-170.

Sharma, N., W. S. Park, R. Vepachedu, L. Barbier, M. Clani, F. Stripe, J. B. Sarvary and M. J. Vivanco. 2004. Isolation and characterization of an RIP (Ribosomal Inactivating Protein)-like protein from tobacco with dual enzymatic activity. Plant Physiol. 134:171-181.

Southern, E. 1975. Detection of specific sequences among DNA fragments separated by gel electrophoresis. J. Mol. Biol. 98:503-517.

Towbin, H., T. Staehelin and J. Gordon. 1979. Electrophoretic transfer of proteins from polyacrylamide gels to nitrocellulose sheets. Procedures and some applications. Proc. National Acad. Sci. USA. 76:4350-4354.

Van Loon, L. C. 1985. Pathogenesis-related proteins. Plant Mol. Biol. 4:111-116.

Yedidia, I., N. Benhamou, I. Chet. 1999. Induction of defence responses in cucumber plants by the biocontrol agent Trichoderma harzianum. Appl. Environ. Microbiol. 65:10611070. 